\section{‘Unintended cities' and inoperative violence. Housing resistance in Yangon}

This paper wishes to build two interconnected arguments: the first, that urban development and city expansion in Yangon happened through the forced resettlement of people from the city toward the periphery, and from periphery to periphery; the second, that resettlement was initiated before the British colony, perpetrated during the colonial period, internalised and expanded by the following post-colonial regimes, and has become by now the main form of statesanctioned space production. We argue that this has been possible thank to the development of laws, orders and policies that justified, legitimised and created the need for dispossession and displacement. Building on Benjamin's and Agamben's essays on violence, we claim that it is possible to interrupt the endless cycle of law and violence by locating violence outside the debate around 'means and ends'. Stemming from the authors' experience and repeated encounters with practices of social mobilisation of women in Yangon over the last five years, we have traced the potential for deactivating the 'signature' of violence in the everyday practices of resistance of urban dwellers in the township of Hlaing Thar Yar in Yangon. Through the incremental occupation, trespassing and building up of peripheral 'vacant' land, organised women's groups are challenging the spatial order established by post/colonial regimes.

Keywords: Spatial Violence, Myanmar, Women resistance, Urban displacement, Agamben, Territorialisation
Deleted: (8813 words)

\section{Deleted: four}




\section{Introduction}

This paper wishes to build two interconnected arguments: the first, that urban development and city expansion in Yangon happened through the forced resettlement of people from the city toward the periphery, and from periphery to periphery; the second, that resettlement was initiated before the British colony, perpetrated during the colonial period, internalised and expanded by the following post-colonial regimes, and has become by now one of the main forms of state-sanctioned space production. We argue that this has been possible thank to the development of laws, orders and policies that justified, legitimised and created the need for dispossession and displacement. While these arguments are not new and have recently gained increasing attention in international scholarship, we wish to situate them within emerging literature on spatial and planned violence, territorialisation, and well-established debates on violence, law and resistance. Building on Benjamin's essay on violence, we argue that it is always the law that realises acts of (spatial) violence, even when it negates them. Following Agamben, however, we claim that it is possible to interrupt the endless cycle of law and violence by locating violence outside the debate around 'means and ends'. The potential for deactivating the 'signature' of violence lies in the everyday practices of resistance of urban dwellers. Everyday resistance has been practiced for long time in Myanmar and is well documented. What is less documented is the incremental occupation, trespassing and building up of peripheral 'vacant' land, through which organised groups challenge the spatial order established by post/colonial regimes in a visible and overt way. These groups do not simply enact a repossession of the urban fringe to shape their own power over the urban expansion process, they literally contribute to the restoration of the commons in a gesture of inversion - whereas the commons can never be expropriated nor appropriated, but can only be used.

Deleted: Through

Deleted: can 
This paper draws from the authors' experience and repeated encounters with practices of social mobilisation of women in Yangon over the last five years. Women for the World (WfW) is a large network of women saving groups, supported by the Asian Coalition for Housing Rights (ACHR). Our understanding of the network has been informed by sustained engagement, discussions and analysis of practices and contexts with and by community activists and leaders. Over five years, we have been exposed to local development in adjacent settlements in the township of HlaingTharYar, along with groups of national and international students and practitioners. We have learnt about people's strategies and governmental techniques with community members, activists, academics, government staff and policy makers ${ }^{1}$

After setting the scene on the complex Myanmar transition and having briefly discussed the forms of violence as formulated by Benjamin and Agamben and especially the notion of inoperativity, the paper presents urban displacement and people's activation strategies as modes of urban production, and it concludes by reflecting on how housing practices are de-facto suspending the law.

\section{Setting the scene on the so called 'transition' in Myanmar}

The word transition has been repeatedly associated with Myanmar politics since 2010. Indeed, the time seems one of transition, with power shifting from actor to actor against the background of a growing economy. In few years, the new administration of Myanmar has furthered a number of reforms towards economic liberalisation, leading to rapid changes, including privatisation of public enterprises in many sectors (telecommunication, banking, energy, and housing) and new

The authors are also part of a research team that has been awarded a British Academy grant for the project "Framing living heritage as a tool to understand spatial violence" Project ID: 557740 (November 2019-November 2021)
Deleted: four

\section{Deleted: four}

Formatted: Font: (Default) Arial, $8 \mathrm{pt}$

Formatted: Font: (Default) Arial, $8 \mathrm{pt}$

Formatted: Font: (Default) Arial, $8 \mathrm{pt}$ 
foreign investment laws that opened up overseas ownership of business ventures. Thein Sein's government has surprised many as it "unleashed external economic reforms, legalised political protests and trade unions; lifted media and internet restrictions; released most political prisoners; and incorporated some civil society groups and even former opponents into advisory bodies" (Jones, 2013:781).

However, the meaning of transition is increasingly subject to academic and media scrutiny, particularly to criticise Western assumptions of long-term isolation and stasis and sudden opening up and democratisation. For instance, Jones (ibid) confronts popular accounts that pose transition as a result of regime breakdown, arguing that everything that has happened in Burma's transition so far has been tightly controlled by a largely undiminished military power. Examining its historical evolution, the hypothesis is that the military came to power because of the fear for political unrest and ethnic-minority separatist insurgencies. Once these fears were sufficiently addressed, the military regime withdrew from power thus setting the rules of the game by disciplining civilians and establishing constrained electoral systems within a 'disciplined democracy' which then led towards imposition of their preferred settlement.

Of a similar account, David and Holliday (2018) define the current regime a 'discipline-flourishing democracy'. They observe that ethnic relations are substantially better than inter-faith and internationality relations in Myanmar. In line with this, they assert that there is sufficient evidence that democracy in Myanmar may not yet be liberal. They, thus, suggest the idea of 'limited liberalism', which means a political culture of hybrid regime. This suggests to them that Myanmar will remain in a "limbo ... for some years to come" (ibid). Farrelly, Holliday and Simpson (2017) point out that the National League of Democracy (NLD), the leading party, continues to hold ties with their old enemies in the armed forces. As matter of fact, the military still holds 25 percent of 
the seats in parliament. For the remaining seats, they are comfortable with NLD taking over legislative and executive powers. Farrelly et al. also note that the current power sharing arrangement between the military and the democratically elected government is "an uneasy coalition".

Transition can hardly be considered a fix point in time, or happening in one direction only. Most likely, there have been different moments of transition and turning points. For instance, according to Seekins (2005), Woods (2011) and Buchanan, Kramer, and Woods (2013) economic liberalisation started well before 2010. Contrary to the common believe, the open economy policy was inaugurated by the State Law and Order Restoration Council (SLORC) in the 1990s. The policy encouraged foreign investment, which in turn boosted construction industry in Yangon lasting to date. This example is illustrative of what Rhoads and Wittekind (2018) have called recurring and cyclical transition. For them, "understanding transition as recurring serves to highlight historical continuity rather than defining the current moment as wholly differentiated from ruptures of the past. Viewed in this way, the current transition underway in Myanmar is not a moment of emergence from isolation, nor productive of a blank slate for investment, but a moment that articulates with previous claims, authorities, and ruptures" (p.186). This also reinforces claims (ibi; Woods 2011) according to which the economic isolation of Myanmar was only partly such. Indeed, while the country was under an embargo sanctioned by the US, Chinese and other Asian investments increased steadily.

Girke and Beyer (2018) offer the probably most exhaustive account of the polyvalence and dissonance of the term transition applied to Myanmar politics. According to them, considering the country 'in transition' is to "serve the disclaimer, a legitimation and explanation of unfulfilled hopes and aspirations" (p.215). Within the academic debate, transition is linked to democracy, 
dialogue, accountability, tension between top-down and bottom-up processes and ceasefires, and is often denoted with missed opportunity. In this sense, it has become an unbound signifier that suggests too little by suggesting too much. Transition is hence used as a label that remains undefined; as a complaint about change; as an empty political science concept when related to actual; and finally as a beacon of hope for those who want to see true democracy in Myanmar.

Within media and popular debates transition is used in a different manner, mostly to facilitate communication with global actors in the liberalised context (Girke and Beyer 2018). The everyday translation of transition means "period of political change", which is less burdened with teleology compared to the English term. In short, the popular account of transition implies that there is an end to a process and that the past has become now malleable. Transition of course denotes modernisation, but intended as a 'migratory model', a shift from a static historical perspective to an analytical one that focus on translations (ibi).

Similarly, Rhoads and Wittekind (2018) argue for a shift from ideas of transition "premised on isolation and decline and towards those centred on interaction and agency" (p.172). According to them, this shift is necessary to step away from narratives built on 'lack' and focus on how narratives on 'change' are reframing the past. Particularly, their argument according to which even in periods archived as 'decline', 'stasis' and 'isolation', land and property were still sites of dynamic change and contestation will be particularly useful to understand the resistive practices discussed later in this paper. 


\section{The Unintended city and its forms-of-violence}

In the span of a decade, between 2010 and today, Yangon has accelerated the speed of urban changes, including privatisation of public enterprises and foreign investment reforms. As a result, investors are flocking in to exploit the city's resources, land and cheap labour, and market forces are making land prices soar. Planning is hardly a public subject (Matelski and Sabrié 2019), and as Kyed (2019) puts it, it is a "continuous battlefield between different overlapping authorities". Planning is mostly characterised by outsourcing (of expertise and knowledge) and Sino-Japanese partition of the most profitable urban land (Huynh, 2017; Dobermann 2016). The Yangon Strategic Plan (JICA 2014; 2018) developed by the Japan International Cooperation Agency at the time of writing has not yet been approved. However, a number of corollary local development plans are increasingly attracting investments from Asian companies in what Percival terms 'intraAsian urbanism' (Percival, 2015:186). As Sarma et al. (2019) have it "Arguably what is especially evident in Yangon's case are the ways that the downtown colonial-built environment provides a domain and organizational template for business, exclusion and power where 'development' is now enacted." (20) Large holdings (with Chinese share-holders historically close to military power) and Japanese Engineering services companies have signed multi-million dollar contracts to build infrastructural nodes, ports, satellite towns and consumption spaces (Forbes, 2016). A number of large and small high-end housing developments are already being built or designed in the inner and outer areas on nominally public owned land. Military officers, government officials and private companies have used confiscated land from resettlement areas to build modern luxury homes on high value sites. New gated communities and condos represent the globalisation of capital, while urban development is de facto monopolised by the market. As Shatkin would put it, this represents the 'transfer of power over and responsibility for the visioning of urban futures and the exercise of social action for urban change from public to private sector actors' (2008:388).
Deleted: less than

Formatted: Font: (Default) Georgia, $10 \mathrm{pt}$, Pattern: Clear

Deleted: It

Formatted: Font: Georgia, $10 \mathrm{pt}$ 
High end residential projects however are not the only developments punctuating Yangon's mixed-use periphery, as they are paired with old and new industrial zones (Forbes, 2016) and affordable housing projects which construction was announced by the Department of Human Settlements and Housing Development (DHSHD) in 2014 and implemented since although with several hiccups. Such housing though is not accessible to poor communities, who keep occupying public interstitial swampy, low lying land in between industrial zones, residential areas and unused infrastructure (ACHR, 2004b; Forbes,2016; Kyed, 2019; Sabrie 2019).

In the face of aggressive commercialisation and alienation of land, and lack of affordable housing alternatives, the urban majority struggle to secure a place for themselves. Most of them lack basic knowledge and sufficient resources to enforce their rights. As people are not inscribed in decisionmaking and planning, it seems the city transforms beyond their control. Borrowing Satterthwaite's (2008) definition, Yangon can thus be seen following the Asian trend of unintended cities, cities where 'what actually developed within and around the urban centre was in large part unintended' and 'much influenced by factors far beyond the control of those who lived there' (p.5). With this definition, Satterthwaite portrays the Asian city as the city that is not intended (planned) for its urban majority. Although the coinage of unintended city was not forged for Yangon specifically, but rather employed to describe the urban development of eight Asian Cities, it well applies to the largest most influential city in Myanmar. The marshy suburbs of Yangon were not intended for the impoverished Burmese groups to settle after been expelled from the city centre during the British rule; the far west end of the city beyond the Hlaing river was not intended to house political dissidents dispersed and displaced after 1988 protests. However the register of unintended city helps us to look at the multiple intentions, explicit and implicit in urban transformations $s_{2}$ as forms-of-violence reproduced despite the intentions of its dwellers, but
Deleted: 2014)

Formatted: Font: Georgia, $10 \mathrm{pt}$

Formatted: Not Highlight

Formatted: Not Highlight

Deleted: Particularly

Deleted: it

Deleted:

Formatted: Not Highlight

Formatted: Font: Not Italic 
also intentionally pursued by the ruler, the government, the market and the private sector in a historical continuum. Over more than a century, Yangon has seen repeated expulsions and forced movements of urban poor, ethnic minorities and political dissidents from the city to the periphery and from periphery to periphery, Such expulsions - common to other cities in the region (Harms, 2016) ${ }^{2}$ - marked the expansion and development of the city. They were deliberate and intentional acts, made possible by laws and discourses developed ad hoc. Yet not everybody agrees, on the intentionality behind eviction as planning. According to Prasse-Freeman (2016) for instance there is no evidence that people were intentionally displaced by the government. More importantly, not everything that happened after the expulsion was under the control of state and dominant elite, As we will further articulate, below, people have territorialisation power, they have the ability to subvert an established spatial order and create a new one For instance, the residents of HlaingTharYar have engaged in a variety of arrangements necessary to position themselves "for substantial changes of how the city operates" (Simone, 2016), challenging regimes of planning and laws that sought to circumscribe their lives, and sometimes even recalibrating them toward more equal ends.

In conclusion, the register of unintended city subsumes the idea of urban formation based on the accumulation of capital and reproduction of the interests of dominant powers overlooking the needs of the vast urban majority. However, there is "movement" beyond this - resistance, mobilisation and acts of reterritorialization that counter state violence. The idea of unintended city is not therefore to be understood as unidirectional, nor as denying agency. Beyond

${ }^{2}$ Harms (2016) for instance argues that the growth of the majority of Asian cities is linked to several interrelated forms of exclusion including paperwork, money, violence, the environment, space, and civility. Each of them can simultaneously. empower or disempower.

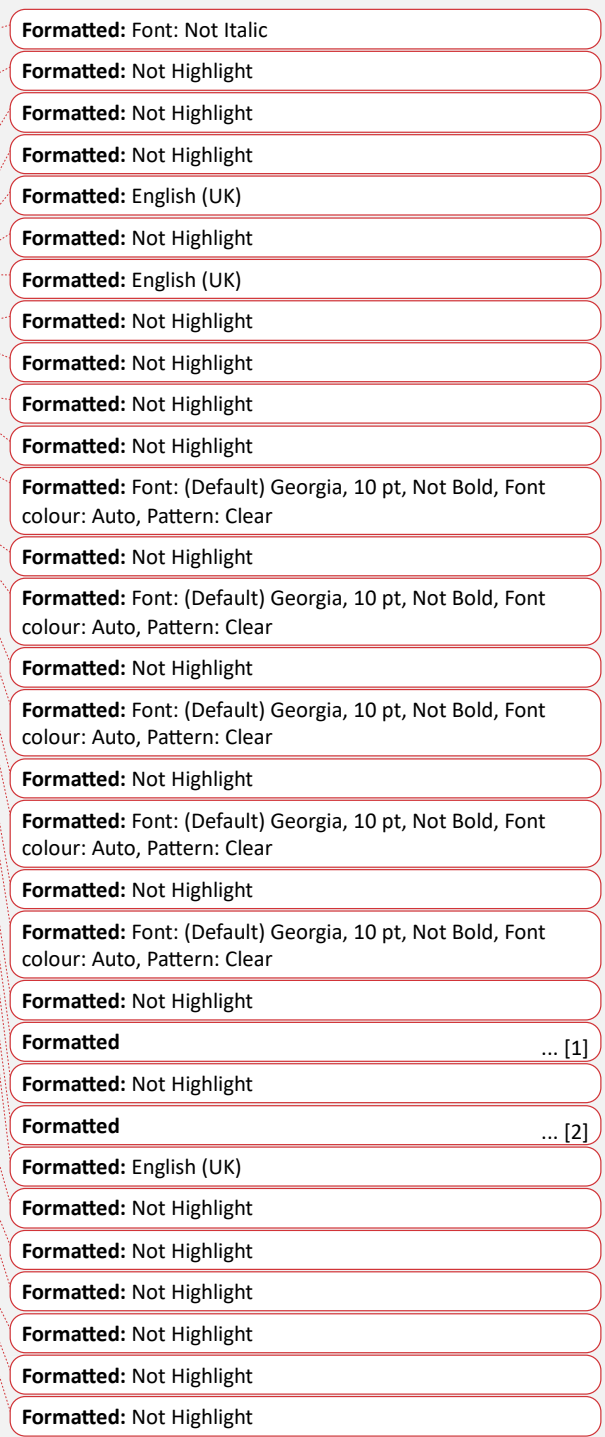


Satterthwaite, the city is rather the operative product of a constant conflict of rationalities and intentionalities, beside the simple duality of intentions and the lack of it.

What follows is a two-part argument. First we explore the ideas of spatial violence, and of violence as continuum, which are useful to understand the repeated evictions and expulsions in Yangon urban history. Then we move onto the concepts of frontier space and ferritorialisation, that are helpful to understand resettlement as a form of biopolitical control over people and space, but also to argue that states are not the only territorialising agents. This will be useful to understand the agency of activist groups such as Women for the World in Yangon.

\section{Violence continuum}

In order to understand the violence continuum in Myanmar, it is useful to recall Rae and Ingala's (2019) conceptual developments in the debate around violence, according to which "violence cannot be reduced to warfare or its physical form", and "violence does not just operate through, but is constitutive of, intersubjective relations, institutions, language, logic, and subjectivity". Which ultimately leads to the claim that "there is something about violence itself that is creative and so necessary for the generation of linguistic, physical, and/or social entities." (p.16). This, for us, is conducive to a definition of violence as a form of social, political and economic order, that is simultaneously destructive and constructive, that is not an interruption but rather a continuous process, that traverses the political history of a country and where space and planning practices are a central agent and not an empty field for other processes to take place.

Undoubtedly, violence is constitutive of Burmese political landscape. "Unelected governments, draconian laws, military tribunals, widespread arrests, torture, forced relocations and portering, mass refugee movements, crackdowns on political leaders, closed universities, repressed freedom

\begin{tabular}{l} 
Formatted: Not Highlight \\
Formatted: Not Highlight \\
Deleted: I \\
Formatted: English (UK) \\
Formatted: Not Highlight \\
Formatted: Not Highlight \\
Formatted: Font: Italic \\
Formatted: Font: Italic \\
Formatted: Fot Hont: Italic \\
Formatted: Not Highlight \\
Formatted: Not Highlight \\
Formatted: Not Highlight \\
Formatted: Not Highlight \\
Foleted: such \\
\hline
\end{tabular}


of the press, expression of speech" are only few of the forms of violence that have and are shaping the history of the country (Jordt 2007:139). This is a violence that is not only felt or experienced in the everyday, but is also "inherent in the junta's justification for rule" (p.139). It is a slow violence (Nixon, 2011) that in turn produces forms of chronic urban trauma (Pain, 2018). Therefore, violence in Myanmar is simultaneously a sustained process and a product of that process that justifies its reproduction. To the point that recent violence and oppression -such as the armed conflicts in the ethnic states - cannot be isolated from the political changes experiences since the British rule.

Following Fanon (2001), lived experience of violence during colonisation are always internalised and reproduced by the colonised. Literally brought into the homes and the minds of the native (p.29), violence remerges later in an inverse analogy. Such process is ubiquitous - it is inherent to language, logic, institutions, relations, law and space - and it is simultaneously destructive and generative, as it produced and reproduces discourses, knowledges, and laws. Linking Fanon's accounts of colonial violence to the practice of urban planning, Boehmer \& Davies (2018) define the latter as the "violent materialization of colonialism's exploitative project" (p.3). 'Planned violence', as they label it, takes place in different forms - from restricted, arrested or forced movement, deportation, encampment, to spatial destitution, exclusion from housing rights, infrastructural and cultural destruction ${ }^{3}$.

${ }^{3}$ According to Soler (2016) repression of freedom of speech and the restriction of freedom of association, were amongst the practices that successive military regimes resorted to that bore a striking resemblance with their British predecessors (also in Edwards 2006). The presence of long lasting Eurocentric practices forced into Myanmar culture during colonisation is also discussed in Ferguson (2015). She highlights how bureaucratic procedures such as census of ethnic groups have been a source of violence historically. Their presence is still felt institutionally and territorially nowadays (see 2014 census)

Formatted: Font: (Default) Arial, $8 \mathrm{pt}$

Formatted: Font: (Default) Arial, $8 \mathrm{pt}$ 


\section{Territorialisation}

Deprivation, dispossession and displacement are all forms of structural violence (Galtung 1991) that also relate to reactionary violence. Much has been written on sustained violence, the normalisation of violence, and the co-existence of violence and democracy especially in countries in political transition (Winton, 2004). Through a closer examination of colonial and postcolonial planning and extractive practices, Rassmussen and Lund (2017) identify two tropes that capture the continuum of planned violence and its dynamics: territorialisation and frontier space. Within the capitalist expansion of resource extraction, frontiers are discursively constructed as vacant or inhabited spaces that can be conquered. By assuming the emptiness of a place, the frontier dismantles any existing institutional, juridical, symbolic and territorial order. In turn, territorialisation establishes a new order, and the two follow each other cyclically. Ultimately, territorialisation is defined as the biopolitical ensemble of tactics and strategies undertaken to control and consolidate space and resources. Resettlement is in particular the privileged instrument employed to secure spatial control. "The capacity to locate and dislocate particular groups to and from spaces on the basis of political identity is central to territorialisation, and the ability to enforce it is crucial for the consolidation of political authority" (p.394).

Frontier space and territorialisation are, a formation process underpinned and sustained by force, enforcement and violence. What is interesting in this account, is that violence is acknowledged as "both part of the destruction of existing rights and the institution and protection of new ones" (p.396) linking back to the idea of violence as generative (Blomley, 2003) and opening up to a condition of possibility. Similarly, Sivaramakrishnan (2019) in the recent essay on 'Assembling Frontier Urbanizations'4 argues that 'frontier ... indicates both exploitation and creation' (p.133).

${ }_{4}^{4}$ The essay is part of a book that examines processes of extraction and production in South East Asia understood as "linked projects of incorporating margins and remote areas into new territorial formations" (p.2). But beyond the study of
Formatted: Font: Italic

Formatted: Not Highlight

Formatted: Not Highlight

Formatted: Not Highlight

Deleted: $\mathrm{T}$

Formatted: Highlight

\section{Deleted: $\mathrm{T}$}

Deleted: is 
While states are the privileged territorialising agents, they are not the only one, as there exist multiple forms of territorialisation. Territorialisation in its generative violence produces authority rather than "those with authority can territorialize" (Rasmussen and Lund:389) Such pluralism and authority-formation process is precisely the starting point of the resistive practices which will be discussed later in the paper.

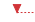

\section{Urban resettlement as a mode of state-sanctioned urban production}

In a recent paper, Rhoads (2018) discusses territorialisation as related to Yangon. After analysing the traces of colonial land control practices in the city, she argues that the British colonial government developed three policies, namely "the annihilation of pre-conquest property rights, the intentional under-equipping and underservicing of Burman majority or outlying areas, and the use of forced evictions in urban development and city expansion" (p.278). Forced evictions worked with logics of 'force' (i.e. forcefully evicting people to make way for development) and territorialisation (by evicting people to expand the territory of the city). Both were operated through a process of expulsion from the city centre, and spatial confinement in satellite towns created ad-hoc: the township logic that was common to other British kingdoms (Bigon, 2016). Further evidence can be found in the fact that during 1962 and 1988 very little urban development occurred in Yangon, yet the administrative boundaries of the city were extended in 1974 . However, expulsions did not work solely from the centre to the periphery, but also from periphery to periphery as is the case of the Resettlement Plan in 1988 that saw the forced removal of thousands of people from the township of Insein to HlaingTharYar (Wai, 2018a, 2018b; Simone

resource frontiers, the book advances the idea of frontier assemblages, as "the intertwined materialities, actors, cultural logics, spatial dynamics, ecologies, and political economic processes that produce particular places as resource frontiers. Frontier assemblage is a term that is both descriptive and analytic." (2

\section{Deleted: Furthermore,}

Deleted: $w$

\section{Deleted: $\pi$}

Formatted: Font: (Default) Arial, $8 \mathrm{pt}$, Italic

Formatted: Font: (Default) Arial, $8 \mathrm{pt}$ 
2016). Those were political opponents to be separated, 'zoned' and 'confined'. In this case resettlement was enacted as a form of depoliticisation through atomisation to neutralise the collective power of the protesters (Seekins 2005; Lubeigt, 2008; Skidmore 2004; Simone 2016).

Forced resettlement as a logic of expansion possibly pre-dated British colonization. According to unpublished research (Tainturier 2019), when royal centres in Burma were to be built, anything that was there and those living there had to relocate to the vicinity. Government-orchestrated forced resettlement to make way for urban development continued during XIX century. Several studies illustrate the early stages of the city formation (Webb 1923; Pearn 1939, Spate and Trueblood, 1942; Maxim 1992). After the British annexation, all land in and around Yangon was declared government property (Lloyd 1911 quoted in Osada 2016; Rhoads 2018) in order to make way for development. This rendered illegal all property rights before annexation. The growth of the city attracted migrants particularly Indians who soon entered in conflict with local Burmese groups5 (Osada 2016). By the end of the century, Indian migrants covered half of the population of Yangon (Bayly, 2003). Overcrowded conditions and increased rents forced low-income Burmese out of the city centre, to unclaimed marshy suburbs to the north_Osada 2016; PrasseFreeman, 2016). Soon after, the colonial government decided to reclaim those lands for residential purposes. Evictions started after the establishment of the Rangoon Development Trust (RDT) in 1921 (Bossom 2007: Rhoads 2018). Those who were evicted had to move to more remote and marshier lands where the RDT had not undertaken clearance yet. Once the informal settlement was cleared, they had to move again. The chain of displacements started in the $1920 \mathrm{~s}$ (Osada, 2016) and marked the beginning of the violent expansion through apartheidisation. 6

${ }_{4}^{5}$ The Indian migrants also took up roles within the colonial administration (Burke 2016, Nawab 2017. Myint 2018) and this fuelled social and ethnic conflict. According to Mynt, Indians became the 'faces of colonialism

\section{Deleted:}

Deleted: This

Formatted: Not Highlight

Formatted: Font: (Default) Arial, $8 \mathrm{pt}$

Formatted: Font: (Default) Arial, $8 \mathrm{pt}$

Formatted: Font: (Default) Arial, $8 \mathrm{pt}$

Formatted: Font: (Default) Arial, $8 \mathrm{pt}$ 
Spatial segregation contributed to social and ethnic conflict between the majority of urban Indians and the impoverished expelled Burmese (ibi 2016). It also led to the creation of a stratified system of property and ownership, that further complicated after independence, nationalisation and changes in the inheritance law (Rhoads 2018). As Seekins (2014) put it "Colonial Rangoon was a product of 'continuous creation through violent means' in which old social patterns and landscapes were uprooted and replaced with new ones that suited the purposes of the British Indian regime: law and order, defense of the empire, profits" (11)7.

Figure 1.

The colonial legacy of forced displacement slightly diluted during the democratic period, although evictions continued. They were carried out in the name of 'cleaning up' the city (Rhoads 2018; Bossom 2007). Three new townships (North Okkalapa, South Okkalapa, Tharkayta) were created between $1950-60$ s to relocate 300,000 squatters evicted from the city centre (Nwe 1998; UNHabitat 1991; Kyed 2019). Under the SLORC regime, Yangon's expansion continued both east and westward with three new townships: Dagon Myothit in the east, HlaingTharYar and Shwepyithat in the west rapidly converting agricultural land into residential one (Seekins, 2005; Sabrié 2019; Lubeigt, 1995). Over half a million residents were relocated from downtown to periphery (Bossom 2007; Seekins, 2014; Kyed 2019) over that period contributing to the doubling of the city (Morley, 2013). Simone (2016) puts the number at 800,00o, arguing that the majority were associated with the 1988 protests. Needless to say, no major effort was made in providing infrastructure and road connections in the new towns. Morley (2013) argues that townships were built to reduce hardship, but in reality the latter was simply moved from the city centre to the

distinct urban regime based on urban trends such as privatization of space, gentrification, urban design, infrastructure development and touristic planning I would propose that the practices substitute for explicit apartheid lecislation (of a sort introduced in the South African case), bringing to the fore new participants in the apartheidization of the city, such as real estate developers and various interest groups" (Yacobi, 2016). 7 And continues: "multi-ethnic Rangoon, a majority of whose people were Indians before World War II, was as much a display of the power (and violence) of the colonial state as the massive buildings erected in the Central Business District"
Deleted: political disputes

Deleted: 7

Deleted: 8

Formatted: Font: (Default) Arial, $8 \mathrm{pt}$

Formatted: Font: (Default) Arial, $8 \mathrm{pt}$ 
periphery. 'Newtown' evictees were generally offered little compensation (Forbes, 2016; HRW, 2018; Kyed 2019), and were often asked to pay for the new plots of land in satellite towns. If they could not pay, they were moved further away and forced to settle in towns with no resources.

Land grabbing, dispossession and continuous displacement were not only pursued in urban environments to 'clean' the core from the 'poor', but also country-wide as part of a 'Burmanisation' policy_Holmes, 1967; South 2007; Brown 2013; Walton, 2013; South and Lall 2017) that fuelled the ethno-religious fonflict, Through the gradual suppression of the customary system, the alienation of the land owned by non-Burmese groups, the transfer of property to the military and the changes in the inheritance rules, the policy produced more informality than before (COHRE,2007; KHRG 2008, 2013; GRET, 2015).. Its primary function was to impose a grid of property rights that served to legitimise the violences of property. The legal system itself was the source of dispossession and violence. Being the country partly closed and isolated, there was no need to globally justify what was going on. The result was a state monopoly that gradually transferred property from non-Burman ethnic nationalities to an elite, military Government, emulating the expropriation and expulsions conducted by the British, in an endless cycle of violence.

Privatisation forces are as central as Burmanisation to understanding socio-spatial inequality in Yangon. When Myanmar opened to the global market and new foreign investments started flowing into the city, land was one of the most attractive assets for new developers. The lack of planning and policy became handy to justify government laissez faire and transfer of power to

${ }_{4}^{8}$ According to Malseed (2009) since 1992, "forced relocation has grown from a means of neutralising non-state spaces to a means of controlling their populations and land, and from a local military tactic to a policy of depopulating entire regions. Local organisations have documented the destruction and dispossession of 3,200 villages throughout Burma since 1996 through such unilateral Tatmadaw action (TBBC 2008)

\begin{tabular}{l} 
Deleted: 2014 \\
Formatted: Font: Font colour: Auto \\
Deleted: $\pi$ \\
Deleted: \\
Deleted: based \\
Deleted: ic \\
Deleted: cleansing and social engineering \\
\hline
\end{tabular}

Formatted: Font: (Default) Arial, $8 \mathrm{pt}$ Formatted: Font: (Default) Arial, $8 \mathrm{pt}$ 
private companies. Not only the nominally democratic government is making little effort in resisting land speculations, confiscation and evictions, but also it largely supporting them. According to Kyed (2019) in June 2017, police drove out 4,000 squatters in one township and destroyed their houses to make way for new high-end developments. Small scale evictions continue to happen in most townships. The government intentionally favours them, through reforms to encourage investment such as the recent Farmland Act. The new law allows the transfer of vast land areas to very few owners, leaving very little vacant land for urban purposes under the control of the government. This means a significant rise in land value following the (technically illegal) plots subdivision for residential purposes. However, with over thirty laws in existence, legal issues on land are extremely complicated.

In a recent paper, Kyed (2019) highlights not only how evictions have roots in the time of the military regime where forced resettlements were commonplace, but also how such practice is sustained by securitisation discourse. She argues that informal dwellers and Yangon migrant workers in particular are publicly represented as criminals, portrayed as security threats even though there is no empirical nor statistical evidence. In this light, evictions are justified as security measure to protect the rest of the city.

Figure 2.

\section{On violence, law and inoperativity}

The violence continuum and the sustained employment of evictions and forced resettlement as means toward urban development, expansion and cleansing supported by a well-crafted legal and discursive framework is not new to Burmese scholarship (Kyed 2019; Rhoads and Wittekind, 2018; Marks, 2016; Woods, 2011; Seekins 2014). Our interest is to examine it against an old
Deleted: and

\section{Deleted: and}

Deleted: it

Deleted: a 
western, debate, central to political philosophy: that on state violence and politics that started with key texts such of Sorel's 1906 Reflections on Violence, Benjamin's 1921 Critique of Violence, and the more recent On the limits of violence by Agamben. In all these works, violence is discussed as related to law, justice and use. This allows us to argue that it is always the law that realises acts of violence, even when it negates them. While the first two essays highlight the question of the positive or negative function of violence in the law, the third one pushes the debate beyond the use of violence, toward making violence 'inoperative'. However distant from where such debate originated, we argue that everyday practices of resistance of urban dwellers in the township of HlaingTharYar in Yangon can feed this debate.

Benjamin employs the term "Gewalt", which does not mean violence in the same way that it does in English but more something like force or hegemony. According to him, "where the highest violence, that over life and death, occurs in the legal system, the origins of law just manifestly and fearsomely into existence" (Benjamin, 1996:242). With other words, the law originates at a moment in which violence reaches its peak. Furthermore, as Zartaloudis (2015) puts it, the word Gewalt "refers to both potestas (power) and violentia, it is a term that entails a dual sense: both the negation of the law and its realization" (p.174). This is fundamental to understand the positive and negative use of violence. In the first case, violence is used to fulfill the law; in the second case, violence is used against the law, hence punished by law (through the use of violence).

According to Benjamin, there are two forms of violence. The first one, physical violence, is a way for the state to assert its own existence, its projection over life. This is called "mythic" violence, because it is invented and the state engages in constant and routine violence culminating in "killing, in the death penalty which allows it [...]" (Benjamin, 1996:248). Mythical violence is formed by law-positing and law-preserving state-sanctioned acts of violence. As opposite to mythic violence, there is the "divine violence" (p. 248), a violence that takes place outside of

\section{Deleted: er}

Deleted: western 
juridical structures one that is "lethal without spilling blood" (p.249-50). While mythic violence is "bloody power over mere life for its own sake; divine violence is pure power over all life for the sake of the living" (p.250). Watkin (2015) suggests that such opposition puts violence in relation to Agamben's idea of bare life. "Pure violence does not spill blood; therefore, it does violence to something other than living bodies [...]". And this is "not another form of violence, but the possibility of acting violently towards the oppositional structure of legally sanctioned state violence" (p.142).

Benjamin himself suggests that such opposition is found in the genuine proletarian strike that creates a 'once-and-for-all' rupture to the endless cycle of violence and law. Such rupture consists of a change of ethical relations. "The destruction of state power and violence is not an end but the lived praxis of the proletariat. To end, the violent continuum of the law becomes then not a conquest of power or a reforming progression, but a break [...] It is a whole transformation of the ethical relations of the way of life as such so that in such action” (Zartaloudis, 2015:176).

In his 1970 essay, rather than questioning the use of violence as a means, as Sorel and Benjamin did, Agamben questions the very meaning of violence. For us this ontological shift is of paramount importance to mark the passage from a common understanding of violence as operative - with a function - to that of an inoperative one - without use. So to explain, violence is usually seen as having a function, a use (whether positive or negative) and its existence is legitimated by this function, or use. Contrary to this, Agamben argues that there exists a form of violence that is located outside the dualism of means and ends, and this is a violence without use. This also marks a fundamental shift from violence as a means, to violence without ends. Only by searching for this form of violence without ends, we can expose the unjustifiability of violence. Only by searching for this form of violence without ends, we are actually capable to deactivate the dispositive of violence. 
For Agamben, resistance to violence is not another 'violence' of means. "Rather, it is a violence that negates the self as it negates the other; it awakens a consciousness of the death of the self, even as it visits death on the other" (Agamben, 2015[19770]:236). With this reading, Agamben replaces Benjamin's 'proletarian strike’ with inoperativity: "genuine revolutionary violence does not only depose power (the old law) but also renders power (including its own) inoperative as such; in order to neutralize it as a long-held paradigm of an operation, passage or initiation. In such neutralization, revolutionary violence inaugurates a new reality, but only as the irreparable manner of present reality" (Zartaloudis 2015:180). This would leave the possibility to imagine a full and complete deactivation of each practice - essentially, politics - so that the human condition can stand no longer on the work (operativity), but on inoperativity where contemplation become the renewed existential plot.

The deactivation of such 'signature's of violence implies rethinking the relation between potentiality and actuality; the affirmation of potentiality over production; and, finally, the construction of an ontology of modality through the notion of man as inoperative. What is rendered inoperative is an activity directed toward a goal, a function, in order to open it up to a new use which does not abolish the old one, but rather exposes and exhibits it: "liberating the living man from his biological or social destiny assigns him to that indefinable dimension that we are accustomed to call "politics" (Agamben, 2011a[2007]:251). Such inoperativity is the way to deactivate the violence inherited in the exclusion "it gives potentiality back to them in the form of inoperativity and ineffectiveness. [...] is not the destruction but the deactivation of the law, rendering the law inexecutable" (Agamben, 2005:97). Agamben continues to reflect on inoperativity as a sui generis praxis that consists in rendering all specific powers of acting or doing

${ }_{9}^{9}$ Watkin suggests that signature (signatura) stands for a "mode of distribution of paradigms through time and across discourses [...] suspended between signifier and signified, so rather than being a sign as such, it is what makes a sign intelligible, by determining existence through actual usage" (Watkin, 2014: 4) 
inoperative. "The life, which contemplates its (own) power to act, renders itself inoperative in all its operations and leaves only (its) livability" (Agamben, 2011a[2007]:251). As Boano (2017) suggests "politics is, for Agamben, the fundamental ontological question. The pars constituens of his project - a new politics - is possible only through and with a new ontology that emerges from a gesture of inversion. Agamben does not offer any solution from a higher, alien, distant reality, but discovers some gestures that render inoperative the signature of oppression. A new politics is a redemption that is not simply transcendental and distant, but directed and grounded towards the here-and-now, in this and only this life, in this very world" (p:164). Therefore, a form of affirmation from violence is a praxis that succeeds in exposing and then rendering inoperative all the differential structures that lie at the core of the political exclusionary violent system. But where to find such resistive affirmative practices?

If forced resettlement in Yangon can be seen, with Benjamin, as a form of mythic violence, a violence that is sanctioned by the state, that is posit by the law, and that in turn preserves the law, Yangon also treasures practices of genuine revolutionary violence capable of rendering the law inoperative. The potential for deactivating the 'signature' of violence lies in the everyday resistance encountered in the housing and spatial practices of people living in informal settlements in the township of HlaingTharYar where the authors have engaged in action research since 2015 and that will be presented in the next section.

\section{Everyday resistance, non compliance and inoperativity} that hegemony has long been contested in cities in Burma, and practices of domination and resistance have always been entangled (p.1606). Politics of dissent and culture of resistance have been present throughout the postcolonial history of Yangon. Resistance (Skidmore, 2004), 
resilience (Sabrie 2019) and co-optation (Brenner 2015) that challenged, interrupted or arrested the violence continuum in Burma and Yangon are well documented. The literature can be organised in three groups. The first documents the ethnic conflict and the armed resistance in the ethnic states. The second one documents historical resistance in urban settings, mostly Yangon. From the student protests, to the 1988 uprise and the Saffron revolution, these actions confronted the regime directly. While most of them have been brutally crashed, community networks which formed, afterwards, and the memory of them, were not crashed - they simply vanished underground, (Malseed 2009).

Open contestation during military regime was difficult; oppositional politics was dangerous and to be avoided (Prasse-Freeman 2010), at least, in public. A third group of literature documents how power was challenged and resisted in a more discrete, private, and diffused way. This is what Scott (1985) calls 'everyday resistance' and the 'weapon of the weak', a type of resistance that is blended in everyday life'10. Thawngmung (2019) examines many non overtly confrontational techniques such as passive resistance, negotiation with local authorities, and "accommodating by not disrupting the status quo."11 Tagliacozzo and Chang (2014) build an intimate mosaic of different resistance practices in the ethnic states, from negotiation, to finding ways to escape, to creating an apolitical space. Mullen (2016) explores divestment, sabotage, evading taxation, insubordination, evading reporting, and hidden transcripts as ways to undermine the system. While some scholars might argue that this type of resistance is less effective in terms of changing

${ }_{4}^{10}$ Abundant literature on the subject covers several aspect of everyday resistance as well as resilience. For instance, Soler (2016) focuses on how people in Burma have built postcolonial geographies through mundane acts, constantly negotiating colonial spaces. South et a. (2010) focus on coping mechanism as self-protection. Malseed (2009) argues that the difference between resistance and self-preservation is unclear in Burma, and both work to undermine state

$\frac{\text { control over non-state spaces. Survival is resistance. }}{11 \text { However, an important point the book makes according to Rhoads's review (2020) is that the resourcefulness of }}$ people - namely their ability to cope - has limited state accountability and even might have sustained the violence of the state.
Formatted: Not Highlight

Formatted: Not Highlight

Formatted: Not Highlight

Formatted: Not Highlight

Formatted: Not Highlight

Formatted: Not Highlight

Formatted: Not Highlight

Formatted: Not Highlight

Formatted: Highlight

Formatted: Not Highlight

Formatted: Not Highlight

Formatted: Not Highlight

Formatted: Not Highlight

Formatted: Not Highlight

Formatted: Not Highlight

Formatted: Not Highlight

Formatted: Not Highlight

Formatted: Not Highlight

Formatted: Not Highlight

Formatted: Font: (Default) Arial, $8 \mathrm{pt}$

Formatted: Font: (Default) Arial, $8 \mathrm{pt}$ 
power structures ${ }^{12}$ Scott (1985) goes as far as to say that it is rather a form of collective action. Similarly, Mullen (2016) argues that, despite scale and nature, everyday resistance is foundational to change at broader scale.

According to Prasse-Freeman (2010,2012) forms of resistance were possible thanks to the specific nature of power. While protest happening close to the 'centre' of power were brutally suppressed, a 'political space' was open at the margins, where power was less concentrated. This space escaped central control and enabled the formation and development of civil society groups such as for instance the Women for the World network, Even in context of brutal repression, we should not neglect the role of people agency (KHRG, 2008). Unlikely armed resistance, the main form of resistance in those political spaces at the margin was non compliance (in our words not doing, deactivating an order). Such practice has some resemblance with that of inoperativity proposed in the previous, part of the paper. Malseed (2009) further delves into this concept by examining repression and state-society conflict. His article brings forward three important points: first, that $\underline{\text { state violence is not a form of control but the lack thereof; secondly, that popular resistance occurs }}$ through non-compliance; thirdly, that displacement IS resistance. Unfortunately, the latter is not fully developed ${ }_{1}^{13}$. Even if his reference is to ethnic state rather than the periphery of Yangon, his example is very valid for the case explored in this paper.

${ }^{2}$ Thawnghmung for instance argues that these examples points at the existence of indirect, frequent, and often uncoordinated acts of resistance (2019:11). Sabrie (2019) analysing the resilience of Yangonites notes that people do not verbalise their resilient actions and most of them are not self-aware of their resilience, meaning they do not code it as such.

${ }_{4}^{13}$ The author argues that "iust as displacement represents resistance and not submission, violence against civilians reflects not control but an absence of control, a will to power rather than power itself." (378). He also concludes by saying that "while the state seeks to enforce territorial sovereignty and totalitarian control, people disobey and resist to retain control over lives and livelihoods, develop mutual support networks and a 'supportive subculture'. They are the central actors in this struggle while the armed groups, though important, are an extreme expression of it which is only feasible with civilian cooperation." (386
Formatted: Not Highlight

Formatted: Not Highlight

Formatted: Not Highlight

Formatted: Not Highlight

Formatted: Not Highlight

Formatted: Not Highlight

Formatted: Not Highlight

Formatted: Not Highlight

Formatted: Not Highlight

Formatted: Not Highlight

Formatted: Not Highlight

Formatted: Highlight

Formatted: Font: (Default) Arial, $8 \mathrm{pt}$

Formatted: Font: (Default) Arial, $8 \mathrm{pt}$

Formatted: Font: (Default) Arial, $8 \mathrm{pt}$

Formatted: Font: (Default) Arial, $8 \mathrm{pt}$ 
While much literature examines everyday resistance that is made possible thanks to spaces left uncontrolled by the state, forms of 'territorialisation from below' (created by non-state non market actors) that involve large collective organization of dwellers in visible ways such as Women for the World network (as described in the next section) are less documented. It is possible that the so called transition has opened new broader spaces at the margins ${ }^{14}$ for large self-organised collectives of landless groups to mobilise openly.

\section{Housing resistance in Yangon}

The expansion of Yangon and the formation of HlaingTharYar are geopolitical. HlaingTharYar was created in the 1990 mostly to resettle the protesters of the 1988 uprise and to house large industrial areas 15 that in turn attracted national and foreign capital as well as waves of migrant workers ${ }^{16}$. The township has expanded fast after 2008 cyclone Nargis and it is now a densely populated satellite town lived by diverse groups of climate refugees, long term displaced individuals, and migrants from rural areas (Kyed, 2019; Forbes, 2016, 2019). Displacement and the inherent possibility of being displaced again define the origin and trajectory as well as the socio-spatial order of the township.

Figure 3.

${ }_{14}^{14}$ Prasse-Freeman notes that after 2011 there has been an "explosion of collective social actions emerging around the country to mobilize for, inter alia, constitutional reform, media freedom and protection, education system decentralization, better worker treatment and compensation, responsible environmental protection and stewardship local influence" (2016) Similarly also Rhoads (2020) argues that "voice strategies though formal channels are more

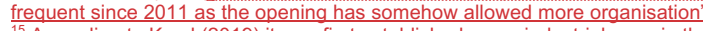
${ }_{15}$ According to Kyed (2019) it was first established as an industrial zone in the late 1980s, and in 1993, it became a residential area as a result of the inner-city relocations. According to Boutry et al (2015) however the development of HlaingTharYar as an industrial zone had to wait for the completion of Bavintnaung Bridge across the Hlaing River in

$\frac{1994 \text { (Nwe 1998). }}{16 \text { However, factory jobs that constitute a pull factor for migrants from rural areas, very rarely provide stable jobs to }}$ migrants (Forbes 2019)
Formatted: Not Highlight

\section{Deleted: ?}

Formatted: Font: Font colour: Auto

Formatted: Not Highlight
Formatted: Not Highlight
Feleted: I
Formatted: Not Highlight
Formatted: Not Highlight
Formatted: Font: (Default) Arial, $8 \mathrm{pt}$
Formatted: Font: (Default) Arial
Formatted: Font: (Default) Arial, $8 \mathrm{pt}$
Formatt: (Default) Arial, $8 \mathrm{pt}$
Formatted: Font: (Default) Arial, $8 \mathrm{pt}$
Formatt: (Default) Arial
Form: Font: (Default) Arial, $8 \mathrm{pt}$
Font: (Default) Arial, $8 \mathrm{pt}$
Forial, $8 \mathrm{pt}$


High internal mobility and extreme wealth inequality characterise the township (Forbes 2019). With a general lack of infrastructure and land provision, displaced people and migrants settle mostly informally. The township has by far the highest number of informal dwellers in the city although data vary according to the source and context, and official census is not available. The urban majority inhabits a vast auto-constructed built environment surrounding golf clubs, garment factories and gated communities. Factories keep attracting migrant workers from rural and other areas of Yangon; while formal and informal housing are mixed in a variety of degrees of tenures, in partly serviced and partly unserviced areas.

\section{Figure 4}

The expansion of the township continues north and west into farm land to house the growing number of dwellers, Informal occupations and development pressure perpetuate an urban regime

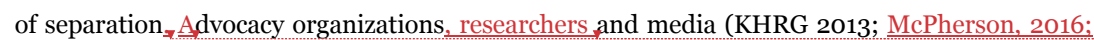
Franco et al. 2016; Kyed 2019) have been vocal in raising awareness around ongoing and imminent evictions in the township. According to Frontier Myanmari ${ }^{17}$, the government is planning to relocate 440,000 informal dwellers to "two townships more than an hour's drive from central Yangon". Given the lack of titling and the ambiguous tenure, people have no legal right to stay nor to be compensated. Legal frameworks around land use and management, ownership issues and customary uses are extremely unclear, to the point that it is difficult to establish whether legal opacity is favouring or hindering people's housing and spatial practices.

$\underline{\text { Several authors have researched this township extensively in recent years (Than Pale 2018; Kyed }}$ 2017, 2019; Forbes 2014, 2019; Simone, 2016). In her last paper, Kyed (2019) examines the complexity and contradictions of land governance in HlaingTharYar. While the urban land is

17.http://www.thisisplace.org/i/?id=3eaa1020-8e5d-4768-bea5-d1abf033ef2a
Deleted: But this is not the only feature.

Formatted: Not Highlight

Formatted: Not Highlight

Formatted: Not Highlight

Deleted: HlaingTharYar

Deleted: population

Formatted: Not Highlight

Formatted: Not Highlight

Formatted: Not Highlight

Formatted: Character scale: $105 \%$

Formatted: Not Highlight

Formatted: Not Highlight

Deleted: While

Deleted: and privatisation forces continue to

Deleted: ,

Deleted: a

Deleted:

Deleted:

Formatted: Not Highlight

Formatted: Not Highlight

Formatted: Not Highlight

Formatted: Font: (Default) Arial

Formatted: Font: (Default) Arial

Formatted: Font: (Default) Arial, $8 \mathrm{pt}$

Formatted: Font: (Default) Arial 
managed solely by the YCDC, peripheral land is owned and managed by the Regional Government, the Ministry of Construction (MoC) and the General Administration Department (GAD) thus creating a chaotic situation, multiple ownership claims, and land sold in various informal and formal ways. Such ambiguity though benefits several groups, from 'professional squatters' (small land owners) to city government officials who 'illegally' purchase and sell or rent land profiting from poor urban dwellers but also accommodating the high demand for housing (although without providing any security).

According to Rhoads and Wittekand (2018) the remote and distant location of many townships has historically allowed customary practices to survive "mostly unchanged in areas where neither colonial authorities nor, until recently, the contemporary Myanmar state have implemented their policies" (p.199). While constituting for urban dwellers a vital source against dispossession and continuous displacement, the authors also argue that customary tenures are a rather complex system of patchy tenures and contested uses. Similarly Simone (2016) notes that people never ceased to mobilise "in multiple modes of savings, buying and selling properties under a variety of legislations, markets and regimes, circumventing the law when necessary"..

While the continuity between the colonial period laws and current reforms that favour land grab is well documented (Ferguson 2014, Marks 2016, Woods 2011), there is less understanding of the complexity of the unfolding of customary use and ownership. Indeed, issues of property in periurban and rural areas are far from simple. Firstly, control over the disposition of land in HlaingTharYar remains to date legally ambiguous (Simone, 2016). Not all land belongs to the state as there are traces of precolonial, colonial and postcolonial private property and multiple claims the same plot of land. The report Our Customary Lands (ECDF, 2016) for instance provides evidence and explains how customary land management systems have co-existed with
Formatted: Not Highlight

Formatted: Not Highlight

Formatted: Not Highlight

Formatted: Not Highlight

Formatted: Not Highlight

Formatted: Not Highlight

Formatted: Not Highlight

Formatted: Not Highlight

Formatted: Not Highlight

Formatted: Not Highlight

Formatted: English (UK), Not Highlight

\section{Deleted: $\mathrm{w}$}

Deleted: As

Deleted: puts it,

Deleted: Furthermore, while nominally customary laws provide women equal rights in relation to land, in practice, however, the rights of many women are practice, however, the rights of many women are
governed by customs that do not afford them equal access to or control over land (USAID 2017). 
national land management in Burma for centuries creating multiple layers of property and right to use. Secondly, there are different understandings of land use in discursive practice. Driving across the township, it is possible to encounter a great amount of apparently empty plots of small and medium size. Land that looks empty, as Rhoads and Wittekand (2018) argue, is never empty. However, such emptiness is increasingly understood by private investors as 'being available' (p.202) which further exposes farmers and informal dwellers of surrounding areas to eviction and relocation.

After 2008, a series of laws concerning land have passed. They have eased land acquisition, transfer and lease of land; and they have increased the demand for rural land and also the cost of rental (Forbes 2019). In particular, the new Farmland Act - allowing farmers to transfer land rights through sale, mortgage, permitting indirect land use rights and codifying inheritance - will have quite an impact on the lives of the people in HlaingTharYar. For this reason, the law has been received in different ways. Mark (2015) argues that the new law will face two major obstacles: clientelism on one side and the legacy of multiple regimes of lands on the other. With an estimate of thirty laws in existence regarding land management, and twenty governmental agencies involved in land management, it is clear that the new law will not capture and protect the full spectrum of land-related rights and former regulations.

According to the organisation WfW, the Farmland act will enable further dispossession and the creation of a land monopoly owned by few land owners. Similarly, to Prasse-Freeman and Win Latt (2019) the legal reforms will make land suddenly officially alienable and transferable. Boutry et a. (2015) on the other side have positively welcomed it as a highly sought 'land turn' for Yangon's development. According to them, the 2012 act has changed the scale of land transactions and the range of actors involved. While before land transactions were done by elites on large 
pieces of land, now the small landholders and villagers will also be able to engage in such transactions. However, as Mark (2015) notes, it is not clear how smallholder farmers will engage with the law, and what informal norms they might use "to strengthen legitimacy of their claims to land against confiscations".

A reply to this question can be found in Simone's (2016) vivid description of land and power dynamics in HlaingTharYar. Particularly he explains how through or despite the new laws, farmers have entered into the property market, diversifying their holdings, making room for diverse land uses and activities. Contrary to Bayat (2000), he argues that farmers engage in revolutionary acts - rather than in a simple urban pragmatism or mere survival to advance their interests.

\section{"[..] the farmers have a kind of secure tenure [..], but they show a kind of willingness to} mess with it, [..] because they feel that in some ways they can scope for themselves a kind of political power [..]. So what you have is ex farm land been used in a lot of different kind of ways which they see as a way they can consolidate an urban basis for themselves [..] it is an interesting kind of move where they sacrifice a certain security intentionally because they foresee their ability to use their holdings as a way to cultivate a particular kind of emerging urban population [...".

Simone also notes that farmers' deliberations over land uses is generally tolerated and land conversion is not blocked, to the point that "a parallel system operates [..] an informal collective institution that impacts and shapes the growth of land economies". This can easily be linked with the everyday resistance and non compliance discussed above. 
Over a period of five years we had the opportunity of observing, analysing and engaging with the land and housing practices undertaken by people in HlaingTharYar. Underpinning such practices there are at least three principles: nalehmu, incrementalism, and resistance. Firstly, in the absence of a system of housing provision and access to basic services, people rely on a social contract that goes under the name of nalehmu literally meaning 'understanding', based either on trust or bribe according to subjective power position. Roberts (2018) states that nalehmu is a "personalized network of implicit mutual obligations, reciprocity and trust established through long term interactions" among community members. She also recognises that this social practice in between the formal and the informal, the legal and illegal is "essential to any kind of life beyond mere survival" (ibid). It is also a network of relationships between individuals, that provides a "sense of security when there is no generalized trust or universal justice" (ibid). In the impossibility of clarifying legal complications, nalehmu supports housing and community driven projects (ACHR, 2010; 2014).

Individuals usually resort to leasing small plots of land through village leaders or other individuals that are managing the land. In some cases, a minimal infrastructure is already existent, in every other case the individuals of a household are responsible for acquiring materials and commencing the building process. Usually people start out by constructing their unit with cheap and precarious materials that gradually get replaced by more stable ones, once the residents can afford to purchase them. This is a form of incrementality that is not linear, as it is often halted by the lack of certainty about the future, the continuous threat of eviction and resettlement, and the lack of security tenure. However we have observed that the greater the uncertainty the greater is the ability of the people to taking over greater risks.

\section{Deleted: four}

\section{Deleted: However,}

Deleted: $\mathrm{t}$

\section{Deleted: Yet}

Deleted: Residents of HlaingTharYar engage in a variety of arrangements necessary to position themselves "for substantial changes of how the city operates" (Simone, 2016), challenging regimes of planning and laws that seek to circumscribe their lives, and sometimes even recalibrating them toward more equal ends. 
Since the mid-20oos, groups of women in HlaingTharYar and other townships in the city started mobilising to claim their housing rights. With the help of organisations such as WfW, women saving groups started to collectively purchase large plots of farmland for building houses for themselves. As a collective, they can afford loans and get credit from the banks. Furthermore, as a collective, future feels less uncertain (Luansang, et a., 2012; Archer, 2012). Purchased land belongs to either the government and/or farmers (who owned the land before its nationalisation, and kept buying and selling it since). In this latter case, even after the purchase, there remains a lack of clarity around land ownership. Nevertheless, new buildings stand upon the land, and they are paid for - waiting for a change in the law, or a change in the land use and a recognition of collective ownership.

Women mobilisation in Yangon is not only aimed to secure resources. Collective savings develop financial and social capital (Boonyabancha and Kerr, 2018; Shand and Colenbrander, 2018); they bring about capacity and empowerment, which in turn enable a different relationship with government agencies - with the hope of influencing planning and policy in the long term. What is interesting to note now is the changing relationship between state and communities as a result of the current transition and how this reflects into social mobilisation and women's networks. When discussing processes of social mobilisation in the Global South, Mitlin (2018) argues that people's strategies do not only show contention, but also complementary forms of collaboration in a complex entanglement between formal and informal leading to forms of partly institutionalised coproduction. This is particularly true for the case of women's network in Yangon which are currently shifting from a quietly revolutionary encroachment (Bayat, 2000) toward more complex form of co-management, co-implementation, co-finance and co-learning. WfW is currently engaging the state in a larger effort of securing land. As noted for other grassroots organisations (Robins, 2008), WfW is displaying a revolutionary pragmatism that allows for 
choosing the best course of action amongst a vast repertoire that is based on resistance as much as subversion, collaboration and even coproduction, on a scale and with a visibility that is possibly new to the context of Yangon,

\section{Deleted: .}

\section{Suspending the law, means without ends}

Yangon, as any other territory, holds multiple systems of organisations, distribution and territorialisation, with divergent claims over space and resources. The coloniser, the military junta and now the nominally democratic government are not the only ones with the ability to territorialise. There are people who have been and are doing the same, as for instance organised women groups in Yangon. Without waiting the cue of legitimacy to take control over land resources, their claim over land in HlaingTharYar for housing purposes is extraordinary in its emulation of imperial, socialist and military practice, and simply ordinary in its embeddedness into a practice that has always been and still is present.

Such women housing practices could be seen as a form of counter-territorialisation, not intended as a practice that removes all existing systems (as was the case for the British coloniser and the military government that followed), but as "a set of processes that preceded legitimacy and authority, fundamentally challenging and replacing existing patterns of spatial control, authority and institutional orders" (Rassmussen and Lund, 2017:388). In this sense, women spatial practices are an act of territorialisation but of an inverse nature, not undertaken by the ruling body, but by the people. In this sense furthermore, women's housing practices constitute a reconfiguration of the conditions of possibility. It is an effort of frontier unmaking, of redefinition of the (urban) frontier, in order to re-signify vacant and uninhabited land, in order to ultimately undo or deactivate an established territorial order. 
The deactivation of established uses and orders is precisely what connects women's practices in peri-urban Yangon with the notion of inoperativity as related to violence and law. By challenging and un-making the spatial order established by post/colonial regimes and governments, women practices build a rupture within the cycle of violence and law. Taking advantage from legal opacity and stratified regimes of property and ownership that make impossible to clearly establish right from wrong, lawful from illegal, housing practices in HlaingTharYar create a zone of indistinction - where law, and therefore violence, are rendered ineffective.

It is paramount however to clarify the subtle difference between repossession and resistance within women praxis in Yangon. As Agamben and even Benjamin before him argued, the potential for deactivating the signature of violence lies in the genuine revolutionary violence, the everyday and ordinary resistance of strikers and urban dwellers. People's practices are multiform remaking of spatial ordering evading the system of surveillance (an art Burmese people have long been trained themselves to). HlaingTharYar people doing however is part of a far more explicit political project of collective resistance. Such resistance to a state sanctioned planned violence that intentionally produce capital accumulation, expulsions and marginalization consists of the reclamation of infrastructures, resources and rights from within, developing a counterintentionality that, from Butler (2011) to Boehmer \& Davies (2018), plays out as "embodied occupation of physical space" (ibid, p.4).

Yet, through the incremental occupation and building up of peripheral vacant land, organised women's groups do not simply enact a repossession of the urban fringe to shape their own power over the urban expansion process, They rather enact an urban form, a city, product of a constant conflict of rationalities and intentionalities, restoring to common use what has been divided, in a

Formatted: Not Highlight

\section{Deleted: $\mathrm{n}$}

Deleted: .

Deleted: F

Deleted: it

Deleted:

Deleted: (Harvey, 2012:5)

Formatted: Not Highlight

Deleted: beside the opposing violent acts of intentions Deleted: $\mathrm{e}$

Deleted: to 
gesture of inversion, of profanation with Agamben. They do so through establishing "the common (or, as others suggest, the same) as point of indifference between the proper and improper- that is, as something than can never be grasped in terms of either expropriation or appropriation, but that can be grasped, rather, only as use" (Agamben, 2000:116). Understanding such inoperative practices and the resultant unintended city, is thus for us fundamental to develop enduring, affirmative relation of subjects that tenaciously respond, non-negatively to aspects of life and to modes of living and violent practices that inhabit the world differently and construct different horizons of hope. The unintended city is not another representation of an exclusionary urban project, nor the operative enactment of spatial violence and their counter-conducts embodied by marginal groups, but rather, the product of a constant conflict of rationalities and intentionalities and indeterminacy, an inoperative terrain where, urban political activities coincide with their neutralization. 


\section{References}

ACHR, 2004a. Negotiating the right to stay in the city. Phnom Penh. Environment and Urbanisation 16:9-26.

ACHR, 2004b. ACHR-Exploratory Visit To Burma / Myanmar.

<http://www.achr.net/upload/files/Burma Exploration 2004 reduced.pdf> [18 Mar. 2019].

ACHR, 2010. Learning and Working with People at Yangon, Myanmar. Yangon.

<http://www.achr.net/upload/files/Learning from People in Myanma(1).pdf> [18 Mar. 2019].

ACHR, 2014. Cyclone Negris opens up big possibilities for people.

<http://www.achr.net/upload/files/Myanmar 11-14.pdf> [18 Mar. 2019].

Agamben, G. 2000. Means Without End: Notes on Politics. University of Minnesota Press.

Agamben, G. 1970[2015]. 'On The Limits of Violence' in Brendan Moran and Carlo Salzani (eds)

Towards the Critique of Violence. Walter Benjamin and Giorgio Agamben. London: Bloomsbury: 231-238.

Agamben, G. 2011[2007] The Kingdom and the Glory: For a Theological Genealogy of Economy and Government. Stanford University Press.

Agamben, G. 2005[2000] The Time that Remains: A Commentary on the Letters to the Romans. Stanford University Press. 
Agamben, G. 2014. 'What is a destituent power?' Environment and Planning D: Society and Space 32(1)

Archer, D. 2012. Finance as the key to unlocking community potential: savings, funds and the ACCA programme. Environment and Urbanization, 24(2): 423-440.

Bayat A. 2000. "From 'dangerous classes' to 'quiet rebels': politics of the urban subaltern in the global South”, International Sociology, 15 (3): 533-557.

Bayly, C. (2003) Rangoon (Yangon) 1939-1949: the death of a colonial metropolis. Centre of Formatted: Justified, Space After: $0 \mathrm{pt}$ South Asian Studies Occasional Paper No. 3, Cambridge.

Bigon, L. 2016 Garden cities and colonial planning: Transnationality and urban ideas in Africa and Palestine. Manchester University Press.

Boano, C. 2017. The Ethics of a Potential Urbanism: Critical Encounters Between Giorgio Agamben and Architecture. Routledge.

Boonyabancha, S., Kerr, T. 2018. Making people the subject: community-managed finance systems in five Asian countries. Environment and Urbanization, 30(1), 15-34.

Benjamin, W. 1996. 'Critique of Violence,' in Selected Writings, 1, 1913-1926, Bullock, M, Jennings, W, eds. Harvard University Press: 236-252.

Blomley, N. 2003. 'Law, Property, and the Geography of Violence: The Frontier, the Survey, and the Grid.' Annals of the Association of American Geographers, 93:121-141. 
Boehmer, E, Davies, D. 2018. Planned Violence. Post/Colonial Urban Infrastructure, Literature and Culture. Palgrave Mc Millan.

Bosson, A. 2007 Forced Migration / Internal Displacement in Burma with an Emphasis on Government Controlled Areas," Internal Displacement Monitoring Center.

Boutry, M, Some, K. P, Par, S.C., Win, T.M. 2015. Land dynamics and livelihoods in peri-urban Yangon. The case of Htantabin Township. GRET Land tenure project.

Brown, I. (2013) Burma's Economy in the Twentieth Century, Cambridge: Cambridge University Press

Buchanan, J., Kramer, T. and Woods, K. 2013. Developing Disparity: Regional Investment in Burma's Borderlands. Transnational Institute

Centre on Housing Rights and Evictions (COHRE), 2007. Displacement and Dispossession: Forced Migration and Land Rights in Burma. https://openresearchrepository.anu.edu.au/bitstream/1885/46657/3/COHRENovember2007.pdf [ 24 May 2020]

David, R. and Holliday, I., 2018. Liberalism and Democracy in Myanmar. Oxford University Press. Dobermann, T. 2016, Urban Myanmar. Policy Note, Yangon: IGC, URL: https://www.theigc.org/wp-content/uploads/2017/o1/IGC-Urban-Myanmar.pdf.

ECDF (2016) Our customary lands. Report. Ethnic Community Development Forum. [ 13 Mar. 
2019]. <https://www.tni.org/files/article-downloads/our_customary_land_-_eng.pdf>

Fanon, F. 2001 [1961]. The Wretched of the Earth. Penguin.

Farrelly, N. 2013. Discipline without democracy: military dominance in post-colonial Burma. Australian Journal of International Affairs, 67(3): 312-326.

Farrelly, N., Holliday, I. and Simpson, A., 2017. Explaining Myanmar in Flux and Transition. Routledge Handbook of Contemporary Myanmar. Routledge.

Ferguson, J.M. 2014. The scramble for the waste lands: tracking colonial legacies, counterinsurgency and international investments through the lens of land laws in Burma/Myanmar. Singapore Journal of Tropical Geography, 35:295-311

\section{Ferguson, J. 2015. Who's Counting? Ethnicity, Belonging, and the National Census in}

Burma/Myanmar In: Bijdragen tot de taal-, land- en volkenkunde / Journal of the Humanities and Social Sciences of Southeast Asia

Forbes, E.I., 2016. On the Frontier of Urbanization: Informal Settlements in Yangon, Myanmar. Journal of Burmese Scholarship. 197-238.

Forbes, E. 2019. Migration, Informal Settlement, and Government Response: The Cases of Four Townships in Yangon, Myanmar », Moussons, 3.3, 95-117.

Franco, J., Twomey, H., Khu Khu Ju, Vervest, K., Kramer, T. 2016. The Meaning of Land in Myanmar. Transnational Institute. 
Galtung, J., 1991. Peace by Peaceful Means: Peace and Conflict, Development and Civilization, International Peace Research Institute, Oslo.

Girke, F. Beyer, J., 2018. Transition as a Migratory Model in Myanmar. The Journal of Burma Studies, 22(2): 215-241.

GRET. 2015. 'Land Tenure in Rural Lowland Myanmar', Draft Report, September .

Harvey, D. 2012. Rebel cities. From the Right to the City to the Urban Revolution. Verso.

Harms, E. 2016. Urban space and exclusion in Asia. Annual review of anthropology. 45:45-61.

Human Right Watch, 2018. Myanmar: Farmers Seek Return of Seized Land. Report.

Huynh, D. 2017, "Imagined Urban Futures of Yangon", University of Oxford: Tea Circle. Formatted: No underline, Font colour: Auto https://teacircleoxford.com/2017/01/20/imagined-urban-futures-of-yangon/.

JICA, 2018. The updated Strategic Urban Development Plan of Greater Yangon. The project for the strategic urban development plan of the greater Yangon. Final report I. February 2018.

JICA. 2014. A Strategic Urban Development Plan of Greater Yangon. The project for the strategic urban development plan of the greater Yangon. Final report II. January 2014.

Jones, L., 2013. Explaining Myanmar's regime transition: the periphery is central. Democratization 21(5): 780-802. 
Jordt, I., 2007. Burma's mass lay meditation movement : Buddhism and the cultural construction of power. Ohio University Press.

KHRG, 2013. Losing ground: land conflicts and collective action in eastern Myanmar.

KHRG. 2008. Village Agency: Rural rights and resistance in a militarized Karen State. Karen Human Rights Group. https://khrg.org/2008/11/village-agency-rural-rights-and-resistancemilitarized-karen-state [ 24 May 2020 ]

Kyed, H.M. 2019 Informal Settlements and Migrant Challenges in Yangon, Moussons, 33 | 2019, $\underline{6}-94$

Leckie, S. and Simperingham, E., 2009. Housing, Land and Property rights in Burma: The

Formatted: Default Paragraph Font, Font: (Default) Georgia, $10 \mathrm{pt}$, Font colour: Auto, Do not check spelling or grammar, Pattern: Clear

Current Legal Framework. Geneva: Displacement Solutions \& The HLP Institute.

Formatted: Space After: 8 pt, Line spacing: Multiple $1.08 \mathrm{li}$

Formatted: Do not check spelling or grammar

Luansang, C., Boonmahathanakorn, S., Domingo-Price, M. L. 2012. The role of community architects in upgrading; reflecting on the experience in Asia. Environment and Urbanization,

24(2), 497-512

Lubeigt, G. (2008) “Industrial zones in Burma and Burmese labour in Thailand”, in Skidmore, M. and Wilson, T. (ed) Myanmar: The state, community and the environment, ANU E Press, pp. 159-188.

Lubeigt, 1995. Donnes strategiques d'un amenagemnet urbain en Birmaine: de Rangoon a

Yangon in Ctites d'Asie, Les Cahiers de la Recherche Architcturale. 35-6. Pp 141-151

Formatted: Italian 
Malseed, K. (2009). "Networks of noncompliance: grassroots resistance and sovereignty in militarised Burma 1". The Journal of Peasant Studies, 36(2), 365-391.

Matelski, M. Sabrié, M. 2019. Challenges and Resilience in Myanmar's Urbanization: A Special Issue on Yangon, Moussons, 33, 11-31.

Mcpherson, Poppy, 2016, "Evicting the Residents of 555”, Next City, 18 July 2016, URL: https://nextcity.org/features/view/yangon-myanmar-evictions-urban-cleanup-policies. [ 24 May 2020]

Marks, S. 2016. "Are the Odds of Justice 'Stacked' Against Them? Challenges and Opportunities for Securing Land Claims made by Smallholder Farmers in Myanmar." Critical Asian Studies, $48,3: 443-460$.

Mark, S. 2015. Are the Odds for Justice 'Stacked Against' Them? Challenges and Opportunities to Securing Land Claims by Smallholder Farmers in Myanmar.

<http://www.burmalibrary.org/docs21/CMCP 57-Mark.pdf> [ 18 June 2019]

Maxim, S.H. 1992 "The Resemblance in External Appearance: The Colonial Project in Kuala Lumpur and Rangoon." Ph.D. Dissertation. Cornell University_Mitlin, D. 2018. Beyond contention: urban social movements and their multiple approaches to secure transformation. Environment and Urbanization, 30(2), 557-574

Morley, I. 2013. Rangoon. Cities, 31:601-14 
Mullen, M (2016) Pathways that Changed Myanmar. Zed books.

Nebehay, S, Lewis, S. 2017. UNHCR describes Rohingya crises as 'textbook example of ethnic cleansing'.

Nixon, R. 2011. Slow Violence and the Environmentalism of the Poor. Harvard University Press

Nwe, T., 1998. Yangon: The Emergence of a New Spatial Order in Myanmar's Capital City.

Journal of Social Issues in Southeast Asia. 13(1):86-113.

Osada, N. 2016. Housing the Rangoon Poor: Indians, Burmese, and Town Planning in colonial burma. IDE Discussion paper no.561

Pain, R. (2019). Chronic urban trauma: The slow violence of housing dispossession. Urban Studies, 56(2):385-400.

Pearn, Bertie Reginald. 1939. A History of Rangoon. Rangoon: American Baptist Mission Press.

Percival, T. 2015. 'Urban megaprojects and city planning in Phnom Penh.' The handbook of contemporary Cambodia, K. Brickell, S. Springer, eds. Routledge.

Philp, J, Mercer, D. 2002. Politicised Pagodas and Veiled Resistance: Contested Urban Space in Burma. Urban Studies, 39 (9): 1587-1610

Prasse-Freeman, E. (2010) “Retaking power in Burma," Democratic Voice of Burma, 27 July, http://english.dvb.no/analysis/retaking-power-in-burma-pt-i/10923. 
Prasse-Freeman, E. 2012. Power, civil society, and an inchoate politics of the daily in Burma/Myanmar. The Journal of Asian Studies 71 (2), 371-397

Prasse-Freeman, E. 2016. Sedentarized in Motion: Socio-political Consequences of Dispossession, Displacement, Deterritorialization, and Devalorization of Peasants and Poor People in Contemporary Myanmar. Paper presented for Agrarian Studies Spring Colloquium, 5 $\underline{\text { May } 2016}$

Prasse-Freeman, E. 2016. Grassroots protest movements and mutating conceptions of "the political" in an evolving Burma Metamorphosis: Studies in social and political change in $\underline{\text { Myanmar }}$

Prasse-Freeman, E. and Latt, Phyo Win. (2018) "Class and Inequality in Contemporary Myanmar", in Adam Simpson, Nicholas Farrelly and Ian Holliday, eds, The Routledge Handbook of Contemporary Myanmar. New York: Routledge.

Rae, G., Ingala, E. 2019. The Meanings of Violence. From Critical Theory to Biopolitics. Routledge. Rassmussen, M., Lund, C. 2017. Reconfiguring Frontier Spaces: Territorialization and Resource Control. World Development 101:388-399

Rhoads, E, Wittekind, C. 2018. "Rethinking Land and Property in a Transitioning Myanmar: Representations of Isolation, Neglect and Nature”. Journal of Burma Studies, 22, (2): 171-213

Rhoads, E., 2018. Forced Evictions as Urban Planning? Traces of Colonial Land Control

Practices in Yangon, Myanmar. State Crime, 7(2):278-305. 
Rhoads, E (2020) Everyday Economic Survival in Myanmar by Ardeth Maung Thawnghmung. Madison: Wisconsin University Press, 2019, Book review.

https://teacircleoxford.com/2020/04/22/everyday-economic-survival-in-myanmar-by-ardethmaung-thawnghmung-madison-wisconsin-university-press-2019-320-pages/ [ 24 May 2020 ]

Roberts, J. 2018. Nalehmu - Myanmar's common practices of everyday politics. Lecture held at Yangon Technological University, Yangon, Myanmar on 30 May 2018.

Robins, S. 2008. From Revolution to Rights in South Africa, James Currey and University of KwaZulu-Natal Press, Woodbridge and Pietermaritzburg.

Sabrié, M. 2019, "Yangon 'Emerging Metropolis': Challenges for the Authorities and Resilience of the Yangonites", Moussons, 33: 33-64.

Sarma, J Sidawa J 2019. Securing Urban Frontiers: A View of International Journal Of Urban And Regional Research. P.1-22

Satterthwaite, D. 2008. 'Understanding Asian Cities: a synthesis of the findings from eight city case studies.' Global Urban Development, 4:1-24.

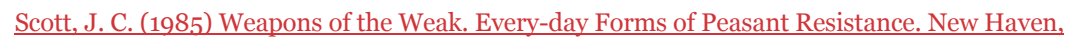
CT: Yale University Press.

Seekins, D. M. 2005. The state and the city: 1988 and the transformation of Rangoon. Pacific Affairs. 78(2): 257-275 
Seekins, D., M. 2014. State and Society in modern Rangoon. Routledge.

Shand, W., Colenbrander, S. 2018. Financing the inclusive city: the catalytic role of community savings. Environment and Urbanization, 30(1): 175-190

Shatkin, G. 2008. The city and the bottom line: Urban Megaprojects and the Privatization of Planning in Southeast Asia. Environment and Planning A, 40(2):383-401

Skidmore, M. 2004. Karaoke Fascism: Burma and the Politics of Fear. Philadelphia: University of Pennsylvania

Simone, A., M. 2016. Provisioning the Provisional: Ensemble Work in Yangon, Antipode RGSIBG 2016 Annual Lecture. <https://www.youtube.com/watch?v=seJvqj6J-dI> [ 18 June 2019]

\section{South, A. 2007. Ethnic Politics in Burma: States of Conflict. Routledge}

$\underline{\text { South, A et a (2010) Conflict and Survival: Self-protection in south-east Burma Ashley South }}$ with Malin Perhult and Nils Carstensen. Asia Programme Paper: ASP PP 2010/04.

https://www.local2global.info/wp-

content/uploads/L2GP_karem_study burma_myanmar_CH.pdf [ 24 May 2020 ]

Spate, O. H. K.; Trueblood, L. W. 1942. Rangoon: A Study in Urban Geography. Geographical Review 32: 56-73.

Tagliacozzo, E. Chang, W 20154 Burmese lives: ordinary life stories under the Burmese regime. Oxford University Press

Formatted: Tab stops: $12.15 \mathrm{~cm}$, Left

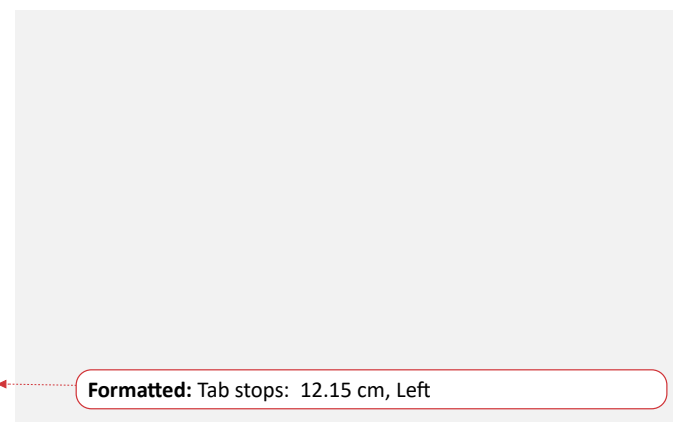


Tainturier, F. 2019. Mandalay and the Art of Building Cities in Burma, Royal Asiatic Society, London-NUS Press, Singapore (forthcoming).

United Nations Centre for Human Settlements (Habitat), 1991. Human Settlements Sector $\underline{\text { Review Union Of Myanmar. https://www.burmalibrary.org/docs4/Habitat report.pdf [ } 24 \text { May }}$ 20201

USAID. 2017. Burma land tenure and property rights profile. Report.

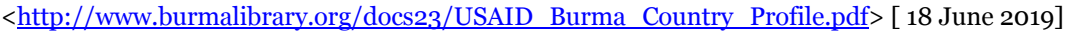

Wai, P. 2018a. "Drama of a Town” Independent Journal of Burmese Scholarship. 1(2) Special Issue on Everyday Justice

Wai, P. 2018b. "Understanding an Involuntary Squatters Movement: How Forced Migration Effects an Urbanized Locality and Its People (A Case Study of Forced Relocation from Insein to HlaingTharYar in the year 1989)”

Walton, M. 2013. The "Wages of Burman-ness:" Ethnicity and Burman Privilege in Contemporary Myanmar. Journal of Contemporary Asia 43(1)

Watkin, W. 2014. Agamben and Indifference: A Critical Overview. London: Rowman and Littlefield.

Watkin, W. 2015. Agamben, Benjamin and the indifference of Violence. Moran, B. and Salzani, C. eds. Towards the Critique of Violence. Bloomsbury Press. 
Webb, C.M. 1923. The development of Rangoon. Town Planning review 10, pp.37-42

Winton, A. 2004. Urban violence: a guide to the literature. Environment \& Urbanization, 16 (2)

Woods, K. 2011. "Ceasefire Capitalism: Military-Private Partnerships, Resource Concessions and Military-State Building in the Burma-China Borderlands", The Journal of Peasant Studies 38(4): $747-770$

Yacobi, H 2016. From 'Ethnocracity' to Urban Apartheid: The Changing Urban Geopolitics of Formatted: Font: (Default) Georgia, $10 \mathrm{pt}$, Not Italic, Font Jerusalem $\backslash$ al-QudsCosmopolitan Civil Societies Journal 2016, 8(3): 5107

Zartaloudis, T. 2015. Violence Without Law? On Pure Violence as a Destituent Power. Moran, B. and Salzani, C. eds. Towards the Critique of Violence. Bloomsbury Press. 169-186. 
Page 9: [1] Formatted

Hewlett-Packard Company

29/05/2020 08:51:00

Font: (Default) Georgia, 10 pt, Not Bold, Font colour: Auto, Pattern: Clear

Page 9: [2] Formatted

Hewlett-Packard Company

29/05/2020 08:51:00

Font: (Default) Georgia, 10 pt, Not Bold, Font colour: Auto, Pattern: Clear 